\title{
Influence of S-STEM Funding: Challenges and Successes
}

\section{Dr. Mo Ahmadian, Eastern New Mexico University}

Dr. Mo Ahmadian is a professor of Electronics Engineering Technology at Eastern New Mexico University. He also serves as ABET/TAC program evaluator for Electronics and Computer Engineering Technology programs. He received his B.S., M.S., and Ph.D. in Electrical Engineering from the University of Missouri-Columbia. Before starting Ph.D. work, he worked three years as a project engineer. 


\title{
Influence of S-STEM Funding: Challenges and Successes
}

\begin{abstract}
This article presents a summary of the four years of activities of the National Science Foundation (NSF) Scholarships in Science, Technology, Engineering, and Mathematics (S-STEM) that includes descriptions of one hour course used, expectations required from scholarship recipients (scholars) and their responses to a survey. The S-STEM program at our institution provided scholarships for financially eligible students in Biochemistry (BIOCH), Biology(BIOL), Chemistry (CHEM), Computer Information System (CIS), Computer Science (CS), Electronics Engineering Technology (EET), and Mathematics (MATH) for the past four academic years (Fall-2009 through Spring-2013). Principal investigators (PIs) activities included proactive recruitment and advertising; offering a one-credit course every fall semester that provided students with skills in job interviewing; teamwork; learning about the future job market and some business skills, plus active mentoring and tutoring. As shown in Table 1, a total of 115 scholarships were given to for the duration of the award. Some students received scholarships for multiple years. The main goal of the S-STEM project was to enable academically talented students, with financial need as defined by the federal government, to either enter a STEM discipline (in order to complete their bachelor degree and then enter the workforce) or to pursue a graduate degree.
\end{abstract}

The Table 1 below provides information on the number of scholarships given and the demographic of scholars.

\begin{tabular}{|l|c|c|c|c|c|c|c|}
\hline Discipline & $\begin{array}{c}\text { \# of } \\
\text { Scholarships }\end{array}$ & Male & Female & White & Hispanic & $\begin{array}{c}\text { African } \\
\text { American }\end{array}$ & $\begin{array}{c}\text { Native } \\
\text { American }\end{array}$ \\
\hline EET & 15 & 14 & 1 & 11 & 3 & 1 & 0 \\
\hline CS & 12 & 8 & 4 & 9 & 3 & 0 & 9 \\
\hline CIS & 10 & 7 & 3 & 7 & 0 & 3 & 0 \\
\hline BIO-CHEM & 4 & 0 & 4 & 4 & 0 & 0 & 0 \\
\hline CHEM & 12 & 4 & 8 & 7 & 3 & 0 & 2 \\
\hline GEOL & 1 & 1 & 0 & 1 & 0 & 0 & 0 \\
\hline MATH & 8 & 3 & 5 & 4 & 3 & 1 & 0 \\
\hline BIOL & 33 & 13 & 20 & 20 & 12 & 1 & 0 \\
\hline Associate & 20 & 9 & 11 & 12 & 7 & 1 & 0 \\
\hline Total & 115 & 59 & 56 & 75 & 31 & 7 & 2 \\
\hline
\end{tabular}

Table 1. The total number of S-STEM Scholarships awarded as a function of demographics for 2009-10 to 2012-13 academic years. 
Our institution is a Hispanic serving intuition (31.29\% of our students are Hispanic). According to the US Code - Section 1067: Congressional Findings, "As the Nation's population becomes more diverse, it is important that the educational and training needs of all Americans are met; underrepresentation of minorities in science and technological fields diminishes our Nation's competitiveness by impairing the quantity of well prepared scientists, engineers, and technical experts in these fields." 1

The S-STEM scholarship was beneficial to many students for the following reasons: encouraging students to do well academically, constant mentoring, meetings and reminding recipients that lack of high performance would lead to loss of scholarship, teamwork and interacting with peers. Also, time management as well as reducing the number of hours working for income was a big factor in achieving high GPAs. The lack of Free Application for Federal Student Aid (FAFSA) on file for some applicants was a difficult and time consuming process. This article presents detailed information on challenges and successes of the award.

\section{Introduction}

According to a study conducted by J. D. Angrist (MIT) and colleagues, involving 1,600 students at a large Canadian university (the equivalent of an American state university with heavily subsidized tuition), the combination of participation in (a) a scholarship program and (b) academic support services resulted in higher academic achievement and retention for females (but both males and females used support services and peer advising at higher rates) compared to groups of students who participated in either (a) or (b) but not both. In the book Talking About Leaving, Why Undergraduates Leave the Sciences, ${ }^{3}$ it is stated that nationally 40 percent of undergraduate students leave engineering programs, 50 percent leave the physical and biological sciences programs, and 60 percent leave mathematics programs to pursue other non-STEM programs.

Recent findings from the Academic Pathways Study (APS) have shown that among the factors that predict the post-graduation plans of seniors - plans to pursue engineering or non-engineering work and plans to attend engineering or non-engineering graduate school—are students' confidence in their professional and interpersonal skills and their level of intrinsic psychological motivation to study engineering. These two variables, when taken in combination, also distinguish the overall college experience of students. ${ }^{4}$

\section{STEM Major Persistence}

There is little national research available on major retention. Major retention is challenging to measure as students declare majors and never begin coursework. Others begin coursework yet only formally declare majors in their second or even third year of study. According to the American Society of Engineering Education, schools collect that information individually, but there have been no recent studies that have looked at the national trends. A 1988 Engineering Deans' Council reported wide variability in institutional data from four-year engineering schools with overall major retention through graduation ranging from $70 \%$ to as little as $30 \%$. $^{5}$ 


\section{Major Activities \\ 1. Recruiting}

The S-STEM project has had a very proactive recruiting program. An S-STEM website that contains information about the S-STEM grant, application, requirements and contacts was developed. As shown in Figure 1, applicants used this website (http://www.enmu.edu/S-STEM) to submit applications, review the criteria, and contact Principal Investigators if needed. Other recruiting materials included postcards and posters. The postcards and posters contained sufficient information about the scholarship including the address to the S-STEM website. The recruiting activities started by emailing a copy of the postcard to every high school principal in the state of New Mexico. Recruitment included visiting high schools in the Eastern part of New Mexico and Western part of Texas and asking the counselors to disseminate the scholarship information to the math and science teachers as well as senior students. A list of sophomore students in five community colleges within 120 miles of ENMU was requested and received. A flyer about the S-STEM was mailed or emailed to every student on that list. Information was also provided to the faculty and students in math and sciences programs through meetings with the deans of math and sciences at five community colleges.

\section{Scholarships in Science, Technology, Engineering and Mathematics (S-STEM) (http://www.enmu.edu/S-STEM)}

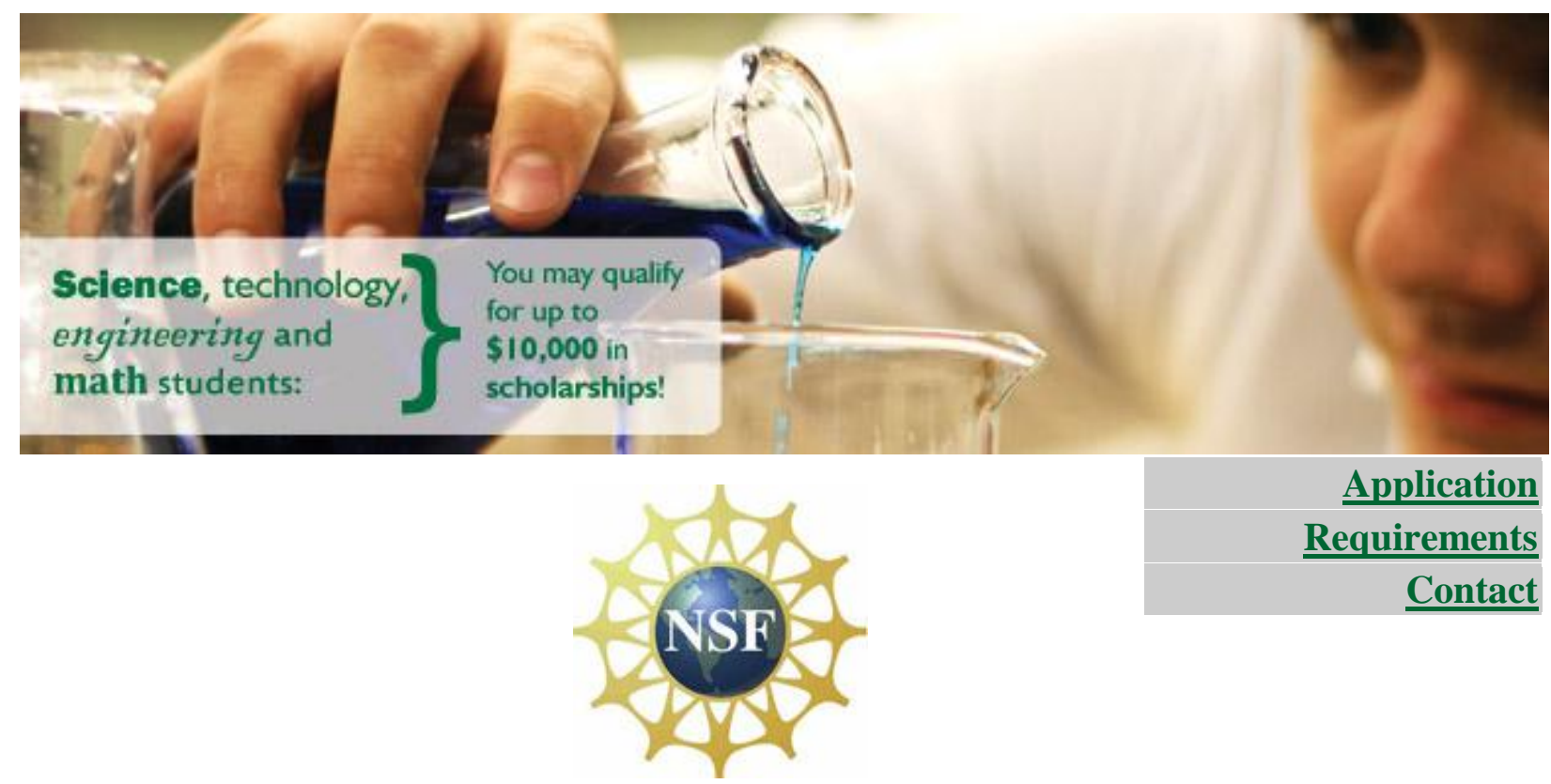

Figure 1. First page of the website

\section{Teamwork}

Teams and teamwork are important components of both industry and organizations. While teamwork is a major component of industry core requirements, the students attending higher 
education institutions may not possess extensive teamwork experience. To help students be effective team members and develop leadership skills in a multidisciplinary environment, $S$ STEM recipients were required to register for a one-credit course that utilizes a team project. Adams and Simon also claim that when individuals have an effective teaming experience the following will occur: a) individually, team members will grow in their understanding of teaming constructs; b) the team as a whole will grow in their understanding of team constructs and c) proper synergy of task and team processes will occur. ${ }^{6}$

To provide students with more information on teamwork, a guest speaker, who had extensive experience in team development and team-working, was invited to the class to speak about effective teamwork. The speaker emphasized the importance of collaboration and discussed Gregoric's Learning Style preferences. The speaker also indicated the importance of equally dividing the work among the team members and explained how team members have an opportunity to evaluate each other's contribution at the end of the project.

\section{Business Concept}

As part of the NSF Scholarships in Science, Technology, Engineering, and Mathematics (SSTEM) grant the scholarship recipients were required to register for a one-credit project course. The course encouraged students to hone their communication skills and gain knowledge in functioning effectively on a multidisciplinary team. Students were provided with a weekly task. The first task in the first year of the S-STEM grant included choosing a company name, and providing descriptions for: the business, product or service, business location, the target market, and the business competition. The final task included "the first year, business survival" such as information on monitoring and evaluation, critical communication and credit, collections, product advances, market trends and summary. In addition to class meetings, students regularly met outside the class to create a PowerPoint presentation. Students were required to demonstrate that they are making progress in understanding the issues involved in having a successful business.

The goal of this project in the first year was to have students achieve competency in business practices equivalent to proficiency realized in engineering subject matters, and to develop leadership among students in a multidiscipline environment. In this course students worked in teams. Each team included 4-5 scholars. The team members were from undergraduate disciplines in mathematics, computer science, electronics engineering technology, biology, computer information systems, chemistry, biochemistry, and geology. To provide mentorship to the freshman students, teams were organized to include students from freshman to senior level and to have students from as many programs in the targeted disciplines as possible. A senior student in each team was appointed as the team leader. Each team chose a conceptual company and provided a weekly presentation for different aspects of the company as requested by the instructor.

To improve students' communication skills, all team members were required to participate in their weekly presentation of equal time. The team members needed to understand the components of the presentation and be very receptive to questions asked by the audience. Furthermore, each team was required to submit a technical report about the team's business plan 
at the end of the semester. Students were provided with the criteria about writing a technical report and inclusion of required materials.

Another goal of this course was to improve student's soft skills. Engineering and science curricula often focus on the technical abilities of students, neglecting the "soft skills" that will often determine success or failure for graduates when they enter the workforce. As an example, project management skills are often neglected in an engineering or science curriculum, requiring additional training for those engineers who end up in management positions. Skills such as the ability to lead and work effectively as a member of a team are frequently identified as critical to the success of an engineer, but typically are lacking in new engineering graduates. ${ }^{7}$

\section{Course Activities ( $1^{\text {st }}$ year)}

In this course students worked in groups. Each group included 4-5 scholars. Each group was to devise a business plan for a marketable product or service. Each student group had a President, Financial Officer, Marketing Specialist, Planning and Analysis person, Sales Manager and so on. Below is the outline that students were to use in developing their proposals. Groups were required to give presentation on a weekly basis. The instructor and other groups used the opportunity to critique each presentation as to clarity, viability, and practicality.

\section{Business Proposal}

- Cover Sheet (Title Page)

- Body (Narrative)

- Financial Section

- Pre-Planning Stages

- Defining the Business

- Getting Ready

- Starting --Action Plan

- Ongoing Operation -- The First Year: Business Survival

The data collected implies that: [1] every team was effective in accomplishing the given task [2] every team member increased his/her teamwork skills [3] every team member had a positive attitude toward the teamwork activity and [4] team member's presentation skills were enhanced significantly. Also, there were some concerns and suggestions that included: [1] it would be more practical to group students in the same discipline [2] the project was too time consuming for one-hour credit [3] some members did not work as hard as others and [4] it would help if there was a speaker at the beginning of the course to discuss a practical business plan. Overall, students agreed that the course provided them with business and teamwork experience including enhanced communication skills.

\section{Marketability}

This course was offered during the fall 2009 semester through fall 2012. On average twenty-five students who were recipients of the NSF S-STEM scholarship registered for the course every year. The first task was to sharpen students resume writing skill. A sample resume was 
provided to the class by the instructor to aid students in the preparation of their resume. Next, to improve student's job interview skill, each student participated in a simulated job interview. For the job interview, each student gave a presentation to the class and discussed why he/she was the best candidate for the given job. The interviewees used their education, experience, personal characteristics to convince the audience that he/she was the best fit for the job. Feedback was provided by the instructor and questions were asked by other students. These job preparation skills helped student be more effective at job career fairs, forced them to have updated resumes, and sharpened their oral communication skills.

\section{Course Activities (The years $2^{\text {nd }}, 3^{\text {rd }}$, and $4^{\text {th }}$ )}

For the actual project, the 25 students were divided in 5 teams with 5 students per team. The task for each team was to choose a real company that hires graduates from their disciplines, interview a person from the company and give a $30-45$ minutes presentation about the company. A set of suggested questions were made available for students to ask the company's representative during the interview. The following list was a suggested set of topics that students may choose to discuss while interviewing a company's representative:

- Company vision

- Company products

- What are secrets to companies?

- What are secrets to individual success?

- How to increase productivity

- Their competitors

- How do they compete?

- How to increase worker's loyalty

- Magic Box: How do you keep the new products secret?

- How do you make sure the workers are happy? High Moral?

- Retirement

- In terms of loyalty on a scale of 1 to 10 , how would you rate yourself?

- What are the strengths and weaknesses of your company?

- Future forecast of your company

- What do you see as a threat to your company?

- What are strengths and weaknesses of your company?

The companies chosen by students were Intel Corporation as shown in Figure 2, ENMR-Plateau Telecommunications, LabCorp, Presbyterian Healthcare Services, Merck \& Company Incorporated, Ward Natural Science, Sandia National Laboratories, Samsung Group, H. Lee Moffitt Cancer Center and Research Institution and Global Technologies, Inc.(GTI). Some teams were able to contact the company's representative quickly, while other teams have to be more aggressive by making multiple calls. 


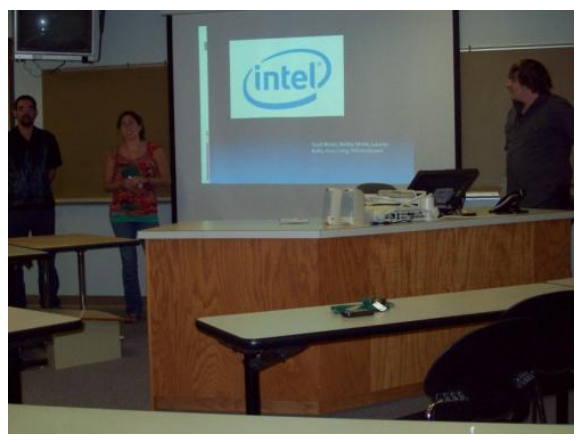

Figure 2. Sample Student Presentation

\section{Evaluation and Assessment}

Adams and Simon argue that highly effective teams exhibit 7 characteristics: common purpose, clearly defined goals, psychological safety, role clarity, mature communication, productive conflict resolution, and team member accountability. An assessment tool was developed that uses these 7 characteristics to assess the effectiveness of teamwork as shown in Tables 2 and 3. It became clear that the teams which were most cohesive tended to develop a more practical and effective job. It seems cohesion is the strength of the relationship linking the members of the group to one another and to the group itself.

As indicated in Table 2, forty-two of the scholars participated in the survey and the majority of students felt that the project they worked on was effective in increasing their teamwork skills. As indicated in Table 2 for the first question "Was your team effective in accomplishing the given task?" 22 students out of 42 rated the project Effective and 18 students rated it as Very Effective. Data in the following tables was collected in two years.

\begin{tabular}{|l|c|c|c|c|}
\hline \multicolumn{1}{|c|}{ Mark only one } & Not at all & Partially & Effective & Very Effective \\
\hline $\begin{array}{l}\text { Was your team effective in } \\
\text { accomplishing the given task? }\end{array}$ & 0 & 2 & 22 & 18 \\
\hline $\begin{array}{l}\text { Were you an effective member of the } \\
\text { team? }\end{array}$ & 0 & 2 & 25 & 15 \\
\hline $\begin{array}{l}\text { Did you increase your own teamwork } \\
\text { skills? }\end{array}$ & 2 & 11 & 20 & 9 \\
\hline $\begin{array}{l}\text { Did you and every team member have a } \\
\text { positive attitude toward the teamwork } \\
\text { activity? }\end{array}$ & 0 & 7 & 13 & 22 \\
\hline $\begin{array}{l}\text { Did every team member behave } \\
\text { professionally toward the teamwork? }\end{array}$ & 0 & 4 & 15 & 23 \\
\hline
\end{tabular}

Table 2. Team Work

As suggested by the speaker, the students should have an opportunity to evaluate themselves and their fellow team members. As indicated in the Table 3, in the "Yourself" column the students rated themselves on average from 4.20 to 4.57 and their fellow team members from 3.47 to 4.47. 
5 = Ideal team member, $4=$ Very good team member, $3=$ Helpful when present, 2 = Causes more problems, $1=$ Quality of work poor

NOTE: unless your group is unique, it is not likely that everyone will receive 5's in every category.

\begin{tabular}{|l|c|c|c|c|c|}
\hline \multicolumn{1}{|c|}{ Collaborative Skills } & Yourself & Member-1 & Member-2 & Member-3 & Member-4 \\
\hline $\begin{array}{l}\text { Common Purpose: was the } \\
\text { main objective of the team } \\
\text { understood and shared by all } \\
\text { team members? }\end{array}$ & 4.32 & 4.47 & 4.32 & 4.27 & 3.65 \\
\hline $\begin{array}{l}\text { Clearly Defined Goals: } \\
\text { were the goals of your } \\
\text { project clearly defined? }\end{array}$ & 4.20 & 4.23 & 4.23 & 4.23 & 3.61 \\
\hline $\begin{array}{l}\text { Role Clarity: was the role of } \\
\text { each member clear? }\end{array}$ & 4.56 & 4.39 & 4.27 & 4.32 & 4.08 \\
\hline $\begin{array}{l}\text { Mature Communication: } \\
\text { was each member } \\
\text { communicating in a mature } \\
\text { fashion? }\end{array}$ & 4.57 & 4.39 & 4.25 & 4.29 & 3.47 \\
\hline
\end{tabular}

Table 3. Evaluation

One of the goals of this project was to improve students' oral communication skills. As indicated in the Table 4, 13 of 42 students felt that their presentation skills were very effective. On a whole the majority ( 23 of 42 students) felt no changes needed to be made in future classes as indicated in the row 2 of the Table 4.

\begin{tabular}{|l|c|c|c|c|}
\hline \multicolumn{1}{|c|}{ Mark only one } & Not at all & Partially & Effective & Very Effective \\
\hline $\begin{array}{l}\text { Did your presentation help you with } \\
\text { your presentation skills? }\end{array}$ & 3 & 12 & 14 & 13 \\
\hline & $\begin{array}{c}\text { No } \\
\text { Change }\end{array}$ & $\begin{array}{c}\text { More } \\
\text { Presentations }\end{array}$ & $\begin{array}{c}\text { More } \\
\text { Individual } \\
\text { Presentations }\end{array}$ & $\begin{array}{c}\text { More Group } \\
\text { Presentation }\end{array}$ \\
\hline $\begin{array}{l}\text { How can we make the presentations } \\
\text { more useful? }\end{array}$ & 23 & 2 & 12 & 5 \\
\hline
\end{tabular}

Table 4. Presentation

The goal of the course was to create an environment where students could work in teams from different STEM programs. An additional goal was to enhance student's communication skills, as well as their ability to work together on team-oriented projects. The data collected was indicative of the same concerns that have been observed in the past years and implies that (1) every team was effective in accomplishing the given task (2) every team member increased 
his/her teamwork skills (3) every team member had a positive attitude toward the teamwork activity and [4] team member's presentation skills were enhanced significantly. There were some concerns and suggestions that included: (1) it would be more practical to group students in the same discipline (2) the project was too time consuming for one-hour credit (3) some members did not work as hard as others. Overall, students agreed that the course provided them with business and teamwork experience as well as it enhanced their communication skills.

\section{Challenges: What has been more difficult than you originally thought?}

One of the difficult and time consuming processes was lack of Free Application for Federal Student Aid (FAFSA) on file for some of the applicants. No applicant can be awarded a scholarship without waiting for information on unmet financial need from the financial aid office. Also, we found that it has been more difficult than originally thought in encouraging students to submit the necessary paperwork for scholarships, admission, and transfer in a timely manner. Outreach to high schools is a more than full time job for the PIs. Especially when senior students need to know the dollar amount of the scholarship they receive before making decision on what university to attend and what major to choose.

It was difficult to attract undecided students to the STEM disciplines because of the mathematics requirements. A large portion of high school students are not interested in taking courses in mathematics and they choose non-STEM majors with less emphasis on mathematics.

We feel that more students can be attracted to STEM disciplines if STEM faculty members from universities will conduct interesting STEM laboratory assignments at high schools in their MATH and science courses.

\section{Successes}

The project has had many successes and positive impacts to report;

- High academic performance: active mentoring, weekly meetings, discussing time management, and encouraging students to do well to receive the S-STEM scholarship, and academic tutoring as needed has contributed in improved scholars' academic performance.

- Multidisciplinary teamwork experience: encouraging students to be contributing members of their team, and the ability to lead and work effectively as a member of a team, having a positive attitude toward a common goal have had a positive impact in increasing their team skills in a multidisciplinary environment.

- Soft Skills: improving communication skills, time management, teamwork skills, having positive attitude, performing professionally during the length of the project, and behaving professionally were some of the note worthy skills.

- Easing the financial burden that resulted in less hours of work for income and more time for academic coursework was also a positive factor.

\section{Conclusion}

The S-STEM scholarship was beneficial to many students for the following reasons: encouraging students to do well academically, constant mentoring, meetings and reminding recipients that 
lack of high performance would lead to loss of scholarship were major factors in high academic performance for scholars. Also, time management as well as reducing the number of hours worked for income were big factors in achieving higher academic performance.

Offering this course was to create an environment where students could work in teams from multidisciplinary STEM programs and demonstrate that students can function effectively and gain valuable experience in creating a business, time management and marketing. An additional goal was to enhance student's communication skills, as well as their ability to work together on team-oriented projects. The data collected implies that: [1] every team was effective in accomplishing the given task [2] every team member increased his/her teamwork skills [3] every team member had a positive attitude toward the teamwork activity and [4] team member's presentation skills were enhanced significantly. Overall, students agreed that the course provided them with business and teamwork experience as well as it enhanced their communication skills.

\section{Acknowledgement}

The authors would like to express their sincere thanks and gratitude to the National Science Foundation (NSF) for the Scholarships in Science, Technology, Engineering, and Mathematics (S-STEM) award No. 0806472.

\section{Bibliography}

1. Ononye L.C. (2011), "Progress and lmpact of SET: An NSF S-STEM Scholarship Project" Proceedings of the 2011 American Society for Engineering Education Annual Conference \& Exposition.

2. Massi, L. and Georgiopoulos, M. (2010). "YES: A NSF S-STEM Scholarship Program Experience at the University of Central Florida," Proceedings of the 2010 American Society for Engineering Education Annual Conference \& Exposition.

3. Seymour, E., \& Hewitt, N. (1997). “Talking About Leaving: Why Undergraduates Leave the Science," Boulder, CO: Westview Press.

4. Otto, E., Chen, H., \& Sheppard, S., (2010). "STUDENTS IMPROVING: IDENTIFYING FACTORS THAT SEEM TO MATTER" Proceedings of the 2010 American Society for Engineering Education Annual Conference \& Exposition.

5. Eschenbach, E.A. \& Virnoche M.E. (2011), "Influences of S-STEM Funding: Final Outcomes of Four Year Scientific Leadership Scholars Program Including Improvements to Department Retention Practices" Proceedings of the 2011 American Society for Engineering Education Annual Conference \& Exposition.

6. Stephanie G. Adams, Ph.D., Laura C. Simon Vena, Bianey C. Ruiz-Ulloa and Fernando Pereira. "A Conceptual Model for the Development and Assessment of Teamwork," Proceedings of the 2002 American Society for Engineering Education Annual Conference \& Exposition.

7. Robert S. Weissbach, Jana G. Goodrich, Ralph M. Ford. "Lessons Learned and Best Practices in Multidisciplinary Teamwork and Teaching of a Small Product Realization Course," Proceedings of the 2004 American Society for Engineering Education Annual Conference \& Exposition. 